\title{
Hubungan Penggunaan Smartphone terhadap Ketajaman Penglihatan
}

\author{
Yonathan S. A. Angmalisang, ${ }^{1}$ Maya E. W. Moningka, ${ }^{2}$ Jimmy F. Rumampuk ${ }^{2}$
}

\author{
1Program Studi Pendidikan Dokter Fakultas Kedokteran Universitas Sam Ratulangi, \\ Manado, Indonesia. \\ ${ }^{2}$ Bagian Fisika Fakultas Kedokteran Universitas Sam Ratulangi, Manado, Indonesia \\ Email: yonathanangmalisang@gmail.com
}

\begin{abstract}
Visual acuity is the ability of a person's eyes to distinguish the shapes and details of objects at a certain distance. Decreased visual acuity is still a health problem in society. A person's visual acuity is influenced by refraction, pupil size, light intensity, exposure time, retinal stimulation area, eye adaptation, and eye movement. The use of smartphones has become a necessity of everyday life in society. Several studies have shown that smartphone use can lead to decreased visual acuity. This study aimed to determine whether there is a relationship between smartphone use and visual acuity and the factors that can affect visual acuity due to smartphone use. The research design used was a literature review with journals that can be accessed free full text through PubMed and ClinicalKey. As a result, the smartphone use can lead to DED, myopia, dan blurred vision. In conclusion, there is a relationship between smartphone use and visual acuity
\end{abstract}

Keywords: smartphone, visual acuity

\begin{abstract}
Abstrak: Ketajaman penglihatan adalah kemampuan mata seseorang untuk membedakan bentuk dan detail objek pada jarak tertentu. Penurunan ketajaman penglihatan masih menjadi masalah kesehatan dalam masyarakat. Ketajaman penglihatan seseorang dipengaruhi oleh refraksi, ukuran pupil, intensitas cahaya, waktu pemaparan, area stimulasi retina, adaptasi mata, dan gerakan mata. Penggunaan smartphone sudah menjadi kebutuhan kehidupan seharihari dalam masyarakat. Beberapa penelitian menunjukkan bahwa penggunaan smartphone dapat menyebabkan penurunan ketajaman penglihatan. Tujuan penelitian untuk mengetahui apakah terdapat hubungan penggunaan smartphone terhadap ketajaman penglihatan dan faktor-faktor yang dapat mempengaruhi ketajaman penglihatan karena penggunaan smartphone. Desain penelitian yang dipakai adalah literature review dengan jurnal-jurnal yang dapat diakses secara gratis melalui PubMed dan ClinicalKey. Hasilnya menunjukkan bahwa penggunaan smartphone dapat mengakibatkan DED, miopia dan penglihatan kabur. Sebagai simpulan, terdapat hubungan penggunaan smartphone terhadap ketajaman penglihatan
\end{abstract}

Kata Kunci: smartphone, ketajaman penglihatan

\section{PENDAHULUAN}

Penggunaan gawai saat ini menjadi suatu kebutuhan sehari-hari. ${ }^{1}$ Kebutuhan penggunaan gawai juga mengalami peningkatan pada masa pandemik COVID-19 dimana seluruh negara membatasi kegiatan yang memerlukan kumpul bersama. Pemerintah Indonesia juga menyarankan untuk tidak berkumpul di tempat ramai. ${ }^{2}$ Banyak bidang yang terpaksa harus melakukan kegiatan secara daring. Salah satu yang terkena dampak adalah pembelajaran di sekolah yang tidak dapat lagi dilakukan di gedung sekolah. Menteri Pendidikan Indonesia menganjurkan untuk melakukan pembelajaran secara daring. Pembelajaran daring ini secara tidak langsung mengharuskan para pelajar untuk belajar melalui gawai, seperti smartphone, tablet, komputer, ataupun laptop. ${ }^{3}$

Jumlah pengguna smartphone diperkirakan lebih dari 1,5 miliar pengguna di 
seluruh dunia dan diperkirakan lebih dari 1 miliar smartphone akan terjual pada tahun 2016. ${ }^{4}$ Di Indonesia, pengguna smartphone diperkirakan mencapai $66,31 \%$ pengguna pada tahun 2017 dan di Sulawesi sekitar $43,8 \% .^{5}$ Menggunakan smartphone tentunya memiliki kekurangan, yaitu ukuran layarnya yang kecil. Menatap layar smartphone yang kecil dengan jarak pandang yang dekat dapat menyebabkan mata menjadi tegang, cepat lelah, dan berpotensi mengalami keluhan penglihatan. ${ }^{6}$

Menurut laporan yang diterbitkan oleh World Health Organization (WHO) terutama berdasarkan data populasi yang diperoleh pada tahun 2007 dengan menggunakan definisi gangguan penglihatan jarak jauh sebagai ketajaman penglihatan yang lebih buruk daripada 18/6, diperkiraan ada 158 juta kasus gangguan penglihatan jarak jauh yang disebabkan oleh kelainan refraksi yang tidak diperbaiki pada tahun 2007. Penyebab gangguan penglihatan terbanyak di seluruh dunia adalah gangguan refraksi yang tidak terkoreksi sebanyak 48,99\%, diikuti oleh katarak sebanyak 25,81\% dan Age-Related Macular Degeneration 4,1\%. Sedangkan, penyebab kebutaan terbanyak adalah katarak sebanyak $34,47 \%$, diikuti oleh gangguan refraksi yang tidak terkoreksi sebanyak $20,26 \%$, dan glaukoma sebanyak $8,30 \%$. Lebih dari $75 \%$ gangguan penglihatan merupakan gangguan penglihatan yang dapat dicegah. ${ }^{7}$

Di Indonesia, prevalensi kelainan refraksi menempati urutan pertama dari penyakit mata, yaitu meliputi $25 \%$ penduduk atau sekitar 55 juta jiwa. ${ }^{8}$ Berdasarkan Riset Kesehatan Dasar (Riskesdas) tahun 2013, Sulawesi Utara dan Sulawesi Selatan menempati urutan ketiga dengan prevalensi kebutaan tertinggi di Indonesia sebesar 0,8\% dari jumlah populasi. Angka ini meningkat dibandingkan prevalensi kebutaan pada tahun 2007 yang hanya sebesar $0,5 \%$. Padahal ketersediaan koreksi refraksi pada penduduk umur 6 tahun ke atas menempati urutan ketiga tertinggi nasional, yakni $7,5 \%{ }^{9}$
Berbagai penelitian menunjukkan bahwa terdapat dampak buruk pada penglihatan oleh karena penggunaan gawai. ${ }^{10}$ Penggunaan smartphone menjadi salah satu penyebab penurunan ketajaman penglihatan terutama pada anak-anak yang lebih sering menggunakan smartphone. ${ }^{11}$ Penelitian pada anak-anak di Spanyol menyatakan bahwa anak-anak yang lebih sering menghabiskan waktunya di rumah dengan bermain smartphone, lebih rentan mengalami penurunan ketajaman penglihatan daripada anak-anak-anak yang menghabiskan waktunya dengan bermain di luar rumah. ${ }^{12}$ Penelitian lain di Spanyol menunjukkan bahwa penggunaan perangkat elektronik dapat menyebabkan penurunan frekuensi kedipan mata yang dapat menyebabkan mata kering. ${ }^{13}$

\section{METODE PENELITIAN}

Jenis penelitian yang dilakukan adalah berbentuk literature review (kajian literatur). Pencarian literatur yang berkaitan dengan topik hingga penyusunan dan pembahasan mengenai literatur yang berhubungan dengan topik terkait berlangsung dari bulan September 2020 hingga Desember 2020.

Pencarian data yang memenuhi kajian literatur yang sesuai dengan topik dilakukan secara online. Pencarian secara online dilakukan lewat situs jurnal ilmiah memiliki database yang beragam dan berkualitas, yaitu PubMed dan ClinicalKey dengan kata kunci ((smartphone) OR (phone)) AND ((visual acuity) OR (visual) $O R$ (vision). Peneliti menemukan 2.263 jurnal yang sesuai dengan kata kunci tersebut. Sebanyak 1.137 jurnal dieksklusi karena tidak tersedia artikel free full text. Penilaian kelayakan terhadap 1.126 jurnal free full text dilakukan, jurnal yang duplikasi dan tidak sesuai kriteria inklusi dilakukan eksklusi sebanyak 1.120, sehingga didapatkan 6 jurnal free full text yang akan dilakukan review.

Kriteria inklusi dan eksklusi yang digunakan berdasarkan strategi Population, Intervention, Comparison, Outcomes, dan Study (PICOS). Populasi yang dipakai 
adalah pengguna smartphone tanpa intervensi dan perbandingan. Desain penelitian yang digunakan adalah Cohort, Cross Sectional, Case Control, Controlled Trial, dan Randomized Controlled Trial, dengan menggunakan artikel yang dipublikasi pada 5 tahun terakhir (20152020) serta menggunakan Bahasa Inggris.

\section{HASIL PENELITIAN}

Dari enam jurnal yang telah dipilih berdasarkan kriteria inklusi dan eksklusi, penulis juga telah mengkaji jurnal-jurnal tersebut. Kesimpulan dari tiap-tiap jurnal mendapatkan kesimpulan yang berbedabeda berdasarkan keluaran yang didapatkan dari penelitian tersebut.

Pernyataan bahwa terdapat hubungan mengenai penggunaan smartphone dan dry eye disease (DED) dibahas oleh tiga jurnal yang telah dikaji. Pada jurnal keempat, didapatkan bahwa penggunaan smartphone pada anak-anak sangat terkait dengan DED pediatrik. Namun, aktivitas di luar ruangan tampaknya menjadi pelindung terhadap DED pediatrik. Siswa kelas yang lebih tua di lingkungan perkotaan memiliki faktor risiko DED oleh karena durasi penggunaan smartphone yang lama dan durasi waktu aktivitas di luar ruangan yang singkat. ${ }^{14}$ Pada jurnal kelima, didapatkan bahwa penggunaan smartphone tidak hanya memperburuk indeks gejala subjektif seperti ocular surface disease index (OSDI), visual analogue scale (VAS), dan computer vision syndrome (CVS) tetapi juga menyebabkan ketidakstabilan film air mata dan indeks stres oksidatif pada air mata dan di permukaan mata. ${ }^{15}$ Pada jurnal keenam, didapatkan bahwa prevalensi miopia pada mahasiswa Cina masih tinggi, yang menahan ketegangan mata atau pekerjaan dengan jarak dekat dalam waktu lama dikaitkan dengan DED, dan mahasiswa dengan penyakit mata kering cenderung mengalami gejala kecemasan atau sejenisnya. ${ }^{16}$

Pada jurnal pertama dan ketiga menyatakan bahwa terdapat hubungan penggunaan smartphone terhadap kejadian miopia. Pada jurnal pertama, didapatkan bahwa penggunaan smartphone dan komputer dikaitkan dengan penurunan penglihatan anak-anak, sementara menonton televisi tidak. Hubungan yang signifikan secara statistik antara waktu di luar ruangan pada tengah hari dan miopia yang berkurang dapat mendukung hipotesis bahwa intensitas cahaya berperan dalam efek perlindungan dari waktu di luar ruangan. ${ }^{11}$ Pada jurnal ketiga, didapatkan bahwa dalam studi ini, terdapat tiga temuan utama. Pertama, peningkatan waktu yang dihabiskan untuk aktivitas jarak dekat dekat dan menggunakan perangkat digital dikaitkan dengan tingkat miopia yang lebih tinggi pada anak-anak Spanyol. Kedua, angka prevalensi miopia pada anak usia 5-7 tahun meningkat. Ketiga, anak-anak yang dilaporkan menghabiskan lebih banyak waktu di luar ruangan cenderung tidak menyebabkan miopia. ${ }^{12}$

Pada jurnal kedua menyatakan bahwa penggunaan smartphone selama 60 menit dapat menyebabkan mata lelah dan penglihatan kabur. Mata yang terasa tidak nyaman juga dirasakan pada pengguna smartphone dengan jarak pandang smartphone yang rendah. ${ }^{17}$

\section{BAHASAN}

Berdasarkan hasil-hasil jurnal-jurnal yang telah dipilih, dapat dikatakan bahwa terdapat faktor-faktor dalam penggunaan smartphone yang dapat mempengaruhi ketajaman penglihatan. Beberapa dari penelitian tersebut membuktikan bahwa faktor yang dapat mempengaruhi ketajaman penglihatan adalah jarak pandang smartphone dengan mata dan durasi penggunaan smartphone. Akan tetapi, terdapat juga penelitian yang menyatakan bahwa tidak terdapat hubungan antara perubahan jarak pandang penggunaan smartphone terhadap ketajaman penglihatan. Jurnal-jurnal yang telah dikaji membuktikan bahwa peningkatan jumlah esodeviasi dan miopia merupakan dampak penggunaan smartphone terhadap penglihatan.

Durasi penggunaan smartphone juga berpengaruh pada kelainan refraksi mata, 
yaitu miopia. Penggunaan smartphone selama lebih dari 60 menit dapat menyebabkan miopia. Hal ini terjadi dikarenakan jarak antara smartphone dengan mata kurang dari $20 \mathrm{~cm}$ dan menatap secara terus-menerus selama lebih dari 60 menit. Miopia juga lebih banyak ditemukan pada anak-anak yang lebih sering menghabiskan waktu di dalam rumah dengan menggunakan perangkat elektronik dibandingkan dengan anak-anak yang menghabiskan waktu dengan bermain di luar rumah. Kejadian miopia jarang ditemukan pada pengguna smartphone yang memiliki waktu istirahat dengan menatap ke luar rungan daripada yang secara terus-menerus menatap layar smartphone. ${ }^{18}$

Tabel 3. Metode penelitian masing-masing literatur

\begin{tabular}{|c|c|c|c|c|c|}
\hline $\begin{array}{l}\mathrm{N} \\
\mathrm{O}\end{array}$ & Peneliti & $\begin{array}{l}\text { Tempat } \\
\text { Penelitian }\end{array}$ & Jumlah Sampel & Usia & $\begin{array}{c}\text { Metode } \\
\text { Penelitian }\end{array}$ \\
\hline 1 & Guan $\mathrm{H}^{11}$ & $\begin{array}{l}\text { Cina Barat } \\
\text { Laut }\end{array}$ & $\begin{array}{l}\text { 19,934 siswa dari } 252 \\
\text { sekolah dasar di Cina } \\
\text { Barat Laut }\end{array}$ & $\begin{array}{l}\text { Usia } 10,6 \pm 1,15 \\
\text { tahun }\end{array}$ & $\begin{array}{l}\text { Randomized } \\
\text { Controlled Trial }\end{array}$ \\
\hline 2 & Long $\mathrm{J}^{17}$ & Australia & 18 dewasa muda & $\begin{array}{l}\text { Usia rata-rata } 21,5 \\
\pm 3,3 \text { tahun }\end{array}$ & Controlled Trial \\
\hline 3 & $\begin{array}{l}\text { Peregrina } \\
\mathrm{CA}^{12}\end{array}$ & Spanyol & 7497 anak-anak & Usia 5-7 tahun & Cross-sectional \\
\hline 4 & Jun $\mathrm{HM}^{14}$ & $\begin{array}{l}\text { Paju dan Seoul, } \\
\text { Korea Selatan }\end{array}$ & $\begin{array}{l}916 \text { siswa sekolah } \\
\text { dasar }\end{array}$ & $\begin{array}{l}\text { Kelas } 1-3 \text { SD (7-9 } \\
\text { tahun) dan kelas } 4- \\
6 \mathrm{SD}(10-12 \text { tahun) }\end{array}$ & $\begin{array}{l}\text { Cross-sectional, } \\
\text { Case control }\end{array}$ \\
\hline 5 & Jung $\mathrm{HC}^{15}$ & Korea Selatan & 80 relawan & Tidak disebutkan & Controlled Trial \\
\hline 6 & $\begin{array}{l}\text { Shanshan } \\
\mathrm{Li}^{16}\end{array}$ & Shanghai, Cina & 901 siswa & $\begin{array}{l}\text { Usia } \\
\text { tahun }\end{array}$ & Cross-sectional \\
\hline
\end{tabular}

Tabel 4. Hubungan penggunaan smartphone terhadap penyakit mata lainnya

\begin{tabular}{|c|c|c|c|}
\hline Peneliti & Uji Statistik & $P$-value & Hasil \\
\hline \multirow[t]{4}{*}{ Guan $\mathrm{H}^{11}$} & $\begin{array}{c}\text { Regresi } \\
\text { Multivariat }\end{array}$ & $p<0,001$ & $\begin{array}{l}\text { Terdapat hubungan antara penggunaan komputer, } \\
\text { smartphone, televisi, dan lama di luar ruangan yang lebih } \\
\text { sedikit pada tengah hari dengan Uncorrected Visual Acuity } \\
\text { (UCVA) yang lebih rendah dan prevalensi miopia yang lebih } \\
\text { besar }\end{array}$ \\
\hline & & $p=0,217$ & $\begin{array}{l}\text { Tidak terdapat hubungan antara penggunaan smartphone } \\
\text { selama 1-30 menit dengan ketajaman visual }\end{array}$ \\
\hline & & $p=0,260$ & $\begin{array}{l}\text { Tidak terdapat hubungan antara penggunaan smartphone } \\
\text { selama } 31-60 \text { menit per hari dengan ketajaman visual }\end{array}$ \\
\hline & & $p<0,001$ & $\begin{array}{l}\text { Terdapat hubungan antara penggunaan smartphone lebih dari } \\
60 \text { menit dikaitkan dengan pengurangan UCVA }\end{array}$ \\
\hline \multirow[t]{5}{*}{ Long $\mathrm{J}^{17}$} & Wilcoxon & $p<0,05$ & $\begin{array}{l}\text { Terdapat hubungan penggunaan smartphone selama } 60 \text { menit } \\
\text { dengan peningkatan gejala mata lelah, tidak nyaman, dan blur }\end{array}$ \\
\hline & Spearman & $p=0,03$ & $\begin{array}{l}\text { Terdapat hubungan yang signifikan antara perubahan skor } \\
\text { gejala total dan perubahan jarak pandang }\end{array}$ \\
\hline & & $p=0,03$ & $\begin{array}{l}\text { Terdapat hubungan antara perubahan jarak pandang dan } \\
\text { perubahan skor gejala individu untuk mata 'tidak nyaman'. }\end{array}$ \\
\hline & & $P=0,11$ & $\begin{array}{l}\text { Tidak ada hubungan yang signifikan antara kelelahan mata } \\
\text { dan perubahan jarak pandang }\end{array}$ \\
\hline & & $p=0,59$ & $\begin{array}{l}\text { Tidak ada hubungan antara mata 'kabur' dan perubahan jarak } \\
\text { pandang }\end{array}$ \\
\hline $\begin{array}{l}\text { Peregrina } \\
\mathrm{CA}^{12}\end{array}$ & $\begin{array}{l}\text { Kruskal- } \\
\text { Wallis test }\end{array}$ & $p<0,001$ & $\begin{array}{l}\text { Terdapat hubungan antara penggunaan perangkat elektronik } \\
\text { dan peningkatan prevalensi miopia }\end{array}$ \\
\hline
\end{tabular}


Tabel 5. Hubungan penggunaan smartphone terhadap penyakit DED

\begin{tabular}{|c|c|c|c|}
\hline Peneliti & Uji Statistik & $P$-value & Hasil \\
\hline \multirow[t]{2}{*}{ Jun $\mathrm{HM}^{14}$} & Chi-square & $p<0,001$ & Terdapat hubungan penggunaan smartphone dan DED \\
\hline & test & $p<0,001$ & $\begin{array}{l}\text { Terdapat hubungan jumlah waktu }(3,18 \pm 0,97 \text { jam }) \\
\text { penggunaan smartphone dan DED. }\end{array}$ \\
\hline \multirow[t]{4}{*}{$\begin{array}{l}\text { Jung } \\
\mathrm{HC}^{15}\end{array}$} & $\begin{array}{l}\text { Wilcoxon } \\
\text { signed rank } \\
\text { test, }\end{array}$ & $p<0,05$ & $\begin{array}{l}\text { Terdapat hubungan antara penggunaan smartphone } 1 \text { dan } \\
4 \text { jam dengan VAS (visual analogue scale), kelelahan, } \\
\text { sensasi terbakar, dan kekeringan pada mata. }\end{array}$ \\
\hline & $\begin{array}{l}\text { Mann- } \\
\text { Whitney } U \\
\quad \text { test }\end{array}$ & $p<0,01$ & $\begin{array}{l}\text { Kelompok smartphone menunjukkan skor ocular surface } \\
\text { disease index (OSDI), kelelahan, rasa terbakar, dan } \\
\text { kekeringan yang lebih tinggi daripada kelompok kontrol } \\
\text { pada } 4 \text { jam. }\end{array}$ \\
\hline & & $p<0,01$ & $\begin{array}{l}\text { Pada kelompok smartphone, konsentrasi HEL meningkat } \\
\text { secara signifikan pada } 4 \text { jam dibandingkan dengan pada } \\
\text { baseline dan } 1 \text { jam. }\end{array}$ \\
\hline & & $p<0,01$ & $\begin{array}{l}\text { Kedua kelompok menunjukkan peningkatan ROS dengan } \\
\text { nilai yang lebih tinggi pada kelompok smartphone } \\
\text { dibandingkan dengan kelompok kontrol pada } 4 \text { jam. }\end{array}$ \\
\hline \multirow[t]{2}{*}{$\begin{array}{c}\text { Shanshan } \\
\mathrm{Li}^{16}\end{array}$} & $\begin{array}{l}\text { Person Chi- } \\
\text { Square test }\end{array}$ & $p=0,0407$ & $\begin{array}{l}\text { Terdapat hubungan antara lama ketegangan mata dengan } \\
\text { DED }\end{array}$ \\
\hline & & $p=0,0233$ & $\begin{array}{l}\text { Terdapat hubungan antara menonton melalui smartphone } \\
\text { dan/atau komputer selama lebih dari } 8 \text { jam setiap hari } \\
\text { dengan peningkatan DED. }\end{array}$ \\
\hline
\end{tabular}

Tabel 6. Karakteristik Studi

\begin{tabular}{cll}
\hline $\begin{array}{c}\text { Tahun } \\
\text { Penelitian }\end{array}$ & \multicolumn{1}{c}{$\begin{array}{c}\text { Desain } \\
\text { Penelitian }\end{array}$} & \multicolumn{1}{c}{$\begin{array}{c}\text { Objek } \\
\text { Penelitian }\end{array}$} \\
\hline 2015-2020 & Controlled & Anak-anak \\
& Trialled, & hingga \\
& Randomized & dewasa \\
& Controlled & \\
& Trialled, dan & \\
& Cross-Sectional & \\
\hline
\end{tabular}

Tabel 7. Karakteristik Subjek

\begin{tabular}{cc}
\hline $\begin{array}{c}\text { Total Subjek } \\
\text { Penelitian }\end{array}$ & $\begin{array}{c}\text { Rentang Usia Subjek } \\
\text { Penelitian }\end{array}$ \\
\hline 29346 & Usia 5-40 tahun \\
\hline
\end{tabular}

Miopia dapat terjadi akibat dari mata seseorang yang hanya menatap objek yang jaraknya dekat. Menatap benda yang jaraknya dekat menyebabkan mata harus berakomodasi agar bisa terlihat dengan jelas sehingga bayangan objek yang tadinya jatuh di belakang mata, bisa jatuh tepat di retina. Akan tetapi, jika jarak objek terlalu dekat, maka dapat terjadi adaptasi dari bentuk mata. Bayangan objek yang terlalu dekat, meskipun dengan akomodasi mata, tidak akan bisa membuat bayangan objek jatuh tepat di retina tetapi hanya akan jatuh di belakang retina. Bola mata akan beradaptasi dengan menjadi memanjang sehingga bayangan objek bisa jatuh di tepat di retina. ${ }^{19-21}$

Penelitian lain menunjang pernyataan yang mengatakan bahwa floaters terjadi akibat dari adanya miopia. Pada penderita miopia yang diakibatkan oleh kelainan bentuk mata, yaitu mata menjadi lebih panjang, dapat menyebabnya tertariknya retina sehingga retina bisa robek ataupun terlepas yang biasanya disebut dengan retinal detachment. ${ }^{22,23}$

Pada literatur yang dikaji, beberapa literatur menyatakan bahwa DED terjadi pada kelompok pengguna smartphone dalam jangka waktu yang lama dibandingkan pengguna smartphone yang kurang dari 3 jam. Tingkat kedipan yang berkurang selama penggunaan smartphone secara terus menerus menyebabkan penguapan air mata yang lebih cepat, yang kemudian dapat menyebabkan DED. Penggunaan terminal tampilan video dan 
pembacaan mengurangi tingkat kedipan menjadi 5-6/menit dan menyebabkan peningkatan penguapan air mata dan akomodasi. Penggunaan smartphone secara terus-menerus dianggap dapat mengurangi tingkat kedipan dan mendorong penguapan air mata, sehingga memicu DED. Tindakan berkedip dapat mencegah lapisan lipid dari kontak dengan lapisan lendir, mempertahankan ketebalan lapisan air mata di film air mata, dan menjaga film air mata tetap stabil. ${ }^{13}$ Jumlah kedipan berkurang saat mata fokus pada benda dekat. Hal ini biasanya terjadi pada penderita VDT. Mereka cenderung kurang berkedip ketika fokus pada smartphone untuk waktu yang lama pada jarak yang sangat dekat. Hal ini dapat menyebabkan distribusi air mata dan sekresi air mata yang tidak normal, yang pada gilirannya menyebabkan peningkatan ketidaknyamanan mata. ${ }^{14}$

\section{SIMPULAN}

Terdapat hubungan penggunaan smartphone terhadap ketajaman penglihatan. Durasi penggunaan smartphone lebih dari 1 jam secara terus-menerus dan jarak pandang yang kurang dari $30 \mathrm{~cm}$ dapat menyebabkan DED, miopia dan penglihatan kabur.

\section{Konflik Kepentingan}

Penulis menyatakan tidak terdapat konflik kepentingan dalam studi ini.

\section{DAFTAR PUSTAKA}

1. Panambuhan J, Rumampuk J, Moningka MEW. Hubungan Penggunaan Smartphone dengan Ketajaman Penglihatan Pada Mahasiswa Laki-laki Fakultas Kedokteran Universitas Sam Ratulangi Angkatan 2015. J Med dan Rehabil. 2019;1(3):1-6.

2. Kementerian Kesehatan RI. Peraturan Menteri Kesehatan Republik Indonesia Nomor 9 Tahun 2020 Tentang Pedoman Pembatasan Sosial Berskala Besar Dalam Rangka Percepatan Penanganan Corona Virus Disease 2019
(Covid-19). Kementerian

Kesehatan RI. 2020.

3. Menteri Pendidikan dan Kebudayaan RI. Surat Edaran Nomor 4 Tahun $2 \mathrm{O} 2 \mathrm{O}$ tentang Pelaksanaan Kebijakan Pendidikan dalam Masa Darurat Penyebaran Coronavirus Disease (COVID- 19). 2020.

4. Demirci K, Akgönül M, Akpinar A. Relationship of smartphone use severity with sleep quality, depression, and anxiety in university students. J Behav Addict. 2015;4(2):85-92.

5. Kominfo. Survey Penggunaan TIK Serta Implikasinya Terhadap Sosial Budaya Masyarakat. Badan Penelitian dan Pengembangan Sumber Daya Manusia. 2017.

6. Bogdănici CM, Săndulache DE, Nechita CA. Eyesight quality and Computer Vision Syndrome. Rom J Ophthalmol. 2017;61(2):112-6.

7. Foster PJ, Jiang Y. Epidemiology of myopia. Eye 2014;28(2):202-8.

8. Suroiyah NA, Latifah R, Utomo SA. Evaluation Comparison Image Quality of Breath Hold (SSTSE) and Respiratory Triggering (TSE) Technique to the Examination of Magnetic Cholangiopancreatography (MRCP). Journal of Vocational Health Studies. 2017;1(2):39-43.

9. Badan Penelitian dan Pengembangan Kesehatan Kementerian Kesehatan RI. Laporan Hasil Riset Kesehatan Dasar. RISKESDAS 2013.

10. Christensen MA, Bettencourt L, Kaye L, Moturu ST, Nguyen KT, Olgin JE, et al. Direct measurements of smartphone screen-time: Relationships with demographics and sleep. PLoS One. 2016;11(11):114.

11. Guan H, Yu NN, Wang H, Boswell M, Shi Y, Rozelle S, et al. Impact of various types of near work and time spent outdoors at different times of day on visual acuity and refractive error among Chinese 
school-going children. PLoS One. 2019;14(4):1-13.

12. Alvarez-Peregrina $C, \quad$ Sánchez-Tena MÁ, Martinez-Perez C, VillaCollar C. The Relationship Between Screen and Outdoor Time With Rates of Myopia in Spanish Children. Front Public Heal. 2020;8(October):5-8.

13. Argilés M, Cardona G, Pérez-Cabré E, Rodríguez M. Blink rate and incomplete blinks in six different controlled hard-copy and electronic reading conditions. Investig Ophthalmol Vis Sci. 2015;56(11):6679-85.

14. Moon JH, Kim KW, Moon NJ. Smartphone use is a risk factor for pediatric dry eye disease according to region and age: A case control study Pediatrics and Strabismus. BMC Ophthalmol 2016;16(1):1-7.

15. Choi JH, Li Y, Kim SH, Jin R, Kim YH, Choi W, et al. The influences of smartphone use on the status of the tear film and ocular surface. PLoS One. 2018;13(10):1-16.

16. Li S, He J, Chen Q, Zhu J, Zou H, Xu $X$. Ocular surface health in Shanghai University students: A cross-sectional study. BMC Ophthalmol. 2018;18(1).
17. Long J, Cheung R, Duong S, Paynter R, Asper L. Viewing distance and eyestrain symptoms with prolonged viewing of smartphones. Clin Exp Optom. 2017;100(2): 133-7.

18. Verma N. Controlling Myopia Progression in Children. Int J Med Biomed Stud. 2020;4(8):133-40.

19. Carr BJ, Ph D, Stell WK, Ph D. Clinical aspects \& health care burden Genes may play a role in development of myopia. 2019;(4): 1-44.

20. Leo SW, Young TL. An evidence-based update on myopia and interventions to retard its progression. $\mathbf{J}$ AAPOS. 2011;15(2):181-9.

21. De Jong PTVM. Myopia: Its historical contexts. Br J Ophthalmol 2018; 102(8):1021-7.

22. Walline JJ, Lindsley $\mathrm{K}$, Vedula SS, Cotter SA, Mutti DO, Twelker JD. Interventions to slow progression of myopia in children. Cochrane Database Syst Rev. 2011;

23. Crim N, Esposito E, Monti R, Correa LJ, Serra HM, Urrets-Zavalia JA. Myopia as a risk factor for subsequent retinal tears in the course of a symptomatic posterior vitreous detachment. BMC Ophthalmol. 2017;17(1):1-5. 